\title{
A study by Umberto Eco and his colleagues on the history of early zoosemiotics: Commentary and bibliography
}

\author{
Kalevi Kull \\ Department of Semiotics \\ University of Tartu \\ Jakobi 2, Tartu 51005, Estonia \\ e-mail: kalevi.kull@ut.ee
}

\begin{abstract}
The article provides a commentary on Umberto Eco's text "Animal language before Sebeok", and an annotated bibliography of various versions of the article on 'latratus canis' that Eco published together with Roberto Lambertini, Costantino Marmo, and Andrea Tabarroni.
\end{abstract}

Keywords: cognitive semiotics; history of biosemiotics; medieval semiotics; zoosemiotics

Semiosis assumes choice - even if the organism is not aware of it. For instance, a dog who starts to bark is not an automaton - at least during a brief moment it can (subconsciously) choose either to do so or not. This moment of confusion while facing the possibilities and working out the action is sign process proper - the quantum of communication - that slowly becomes understandable through the semiotic studies of living beings.

The history of zoosemiotic studies is well described in an anthology compiled by Timo Maran, Dario Martinelli and Aleksei Turovski (2011). Its focus is on the 20th century, when zoosemiotics received its name and became institutionalized, earlier views are concisely described under the title "Prehistory" (Maran et al. 2011: 23-29). A broader account is given by Donald Favareau (2010).

Research into the history of early zoosemiotics, preceding the 19th century, has expanded and remarkably intensified in recent years. We may refer here to the recent volume edited by Alison Langdon (2018) about the views on animal languages in the Middle Ages, as well as the works on early views on animal 
communication by Serjeantson (2001), Sayers (2009) and Fögen (2014). ${ }^{1}$ All this is an important reaching out for the earlier centuries of thought on animal communication that would supplement the review of zoosemiotics of more recent times.

Umberto Eco's text "Animal language before Sebeok", first published in this issue of Sign Systems Studies (Eco 2018), was a talk Eco gave in San Marino as an opening speech at a small symposium dedicated to Thomas A. Sebeok. Thomas Sebeok died on 21 December, 2001, and to commemorate him, the International Center for Semiotic and Cognitive Studies (led by Patricia Violi and Umberto Eco) at the University of San Marino organized a symposium titled "Zoosemiotics: from Clever Hans to Kanzi in memory of Tom Sebeok (1920-2001)”, on 29-30 June 2002. The meeting was small indeed - there were five presenters altogether, and maybe the same number of other attendees. The speakers were (in this order): Umberto Eco, Sue Savage-Rumbaugh, Simone Gozzano, Felice Cimatti, and Kalevi Kull. The programme included also Jean Umiker-Sebeok, but unfortunately she was not able to attend the event.

I then asked Eco the text of his talk for publication in Sign Systems Studies, and he sent it to me. However, he said that more work was required to make this unfinished review of the history of early views on animal language more complete as the text included just some casual findings. Thus the file remained unpublished at the time. However, when we met in Milan several years later on 15 January, 2012, Eco mentioned that I could publish it. ${ }^{2}$

Eco's talk followed a joint project he had carried out together with Roberto Lambertini, Costantino Marmo, and Andrea Tabarroni in the early 1980s (for details, see Marmo 2018) on medieval views on animal communication 'latratus canis'). While their work has been left unnoticed in most reviews of the history of biosemiotics, it certainly deserves more attention from a biosemiotic point of view and is a valuable source for any work on early history of zoosemiotic thought. ${ }^{3}$

The theory of general semiotics as developed by Umberto Eco is among those most suitable for biosemiotics, as I see it. At first sight, this statement can seem surprising, for Eco set the lower semiotic threshold rather high - in comparison

1 We may add, for instance, Campbell 2014; Resnick, Kitchell 1996; Crane 2013; Cuneo 2014; Fabry-Tehranchi, Russakoff 2014; Mackenzie, Posthumus 2015, etc.

2 Earlier, a speech held at the University of Tartu in 2009 had been published in the journal (Eco 2009). Starting from 2001, Eco was also a member of the editorial board of Sign Systems Studies.

3 Cf also Percival 1982. As a comparison, for a contemporary study of dog's barking in the context of umwelt-research, see Yin 2002. 
with the views of his friend Thomas Sebeok. ${ }^{4}$ Eco stated very clearly that he did not believe that there existed any choice or space for intepretation for a Pavlovian dog or in communication among lymphocytes. ${ }^{5}$ However, upon closer analysis we can find that Eco developed some tools which can be used for studying the primary forms of semiosis. These tools just need to be supplemented by knowledge in biology to which Eco himself had limited access. By these tools I mean the works of Eco on the general criteria of semiosis, the concept of the semiotic threshold, ${ }^{6}$ the concept of code, the concepts of primary iconicity and primary indexicality, etc. These concepts are not limited to human semiosis. It is a central task of biosemiotics to analyse to what extent the processes of interpretation and choice exist in living beings other than humans, i.e., before acquiring natural language.

Besides his work on the early history of zoosemiotics, writings by Eco in which he addresses biosemiotic problems explicitly are but few, e.g. Eco 1988, discussing immunology; and Eco 2018b, on Giorgio Prodi; ${ }^{7}$ and everything he wrote about the lower semiotic threshold ${ }^{8}$. Biology was not his field. However, his work on cognitive semiotics, for instance, Kant and the Platypus (Eco 1999), largely deals with biosemiotic problems without explicitly saying-this. Eco (2017: 30) writes:

The possibility of continuing to develop a general semiotics remained my principal problem, and new ideas came to me through contact with cognitive studies. In 1985 the little republic of San Marino [...] established a university. For many years I took part in the activities of a Center for Cognitive and Semiotic Studies, directed by Patrizia Violi (my successor as the Chair of Semiotics at the University of Bologna), and in a series of symposia held between 1988 and 2006 I was able to exchange ideas with philosophers working in a variety of areas as well as top experts in cognition. (I limit myself to mentioning Quine, Putnam, Bruner, Halliday, Searle, Davidson, Kripke, Føllesdal, Kaplan, Dennett, Varela, Churchland, Rosch, Fillmore, Bierwisch, Edelman, Fodor, Rorty, and Lewontin.) It was a valuable experience, some traces of which can be found in my Kant and the Platypus, and it oriented me more and more toward a meeting between semiotics and the cognitive sciences. Moreover, my young colleague Massimo Bonfantini, who has made a profound study of Peirce and has edited the Italian translations of a great many of his works, had been talking for some time about Peircean semiotics as a cognitive semiotics.

4 Rodríguez Higuera, Kull 2017.

5 Eco 2017, in Chapter XI, "Starting with semiotics".

6 Eco 1976; 1999: 106-112; see also Nöth 2000; Kull 2017a.

7 On Eco's views on Prodi, see Kull 2018.

8 For a survey of Eco's concept of the semiotic threshold, see Kull 2017a. 
One should notice that Eco's project of the "latratus canis" was not just an essay on occasional discussions of dog's barking in early literature, but focused on the history of distinctions between animal and human signs in general. It surveys some early writings about animal communication and the types of signs animals use (for instance, barking as an interjection). It also confirms Augustine's role in formulating a general notion of the sign..$^{9}$ The topic's importance can be seen not only in the repeated republications of this work by Eco et al., but also in its updating and rewriting.

And one more detail: understanding the early views about differences in human and animal sign systems is also important because the traditional misunderstandings of animal communication that appeared during the Middle Ages have been rather influential until today.

In the bibliography that follows, I have attempted to compile a list of all Italian and English versions of the work by Eco et al., as well as those by Eco on the same topic. Some translations into other languages are also mentioned.

As the group of articles listed below shows, the whole project, that first had been focusing on the Middle Ages, was later expanded to encompass the Early Modern period and the Antiquity. A separate article by one of the co-authors, Andrea Tabarroni, about animal language in ancient linguistic theory should also be mentioned as part of the project (Tabarroni 1988).

\section{An annotated bibliography of the versions of the article on 'latratus canis'}

Eco, Umberto; Lambertini, Roberto; Marmo, Costantino; Tabarroni, Andrea 1984. On animal language in the Medieval classification of signs. Versus 38/39: 3-38. [The revised version of Eco et al. 1985 in English. Notes pp. 23-38.]

Eco, Umberto; Lambertini, Roberto; Marmo, Costantino; Tabarroni, Andrea 1985. Latratus canis. In: L'uomo di fronte al mondo animale nell'alto medioevo: 7-13 aprile 1983. Tomo secondo. (Settimane di studio del Centro italiano di studi sull'alto medioevo 31.) Spoleto: Presso la Sede Centro, 1181-1230.

[The original Italian version of a paper presented in Spoleto in 1983, with a discussion of the topic by Davide Bigalli, Umberto Eco, and Andrea Tabarroni at the end (pp. 1227-1230). Reprinted as Eco et al. 2016. In English as Eco et al. 1984.]

9 For instance, as John Deely confirmed, he learned about the revolutionary role of Augustine from this article by Eco et al. (see Kull 2017b). 
Eco, Umberto 1985. Latratus canis. Tijdschrift voor Filosofie 47(1): 3-14.

[In English. Text of the lecture given at the Philosophical Society of Leuven on 19 May, 1984. Includes Eco's footnote (p. 3): “This paper simply summarizes and elaborates upon some aspects of a broader research I made in 1983 with the collaboration of three other authors".]

[Translation into Russian: Эко, Умберто 2017. Latratus canis. (Перевод с англ.: Григорий С. Горбун.) Vox medii aevi 1: 146-162.]

Eco, Umberto; Lambertini, Roberto; Marmo, Costantino; Tabarroni, Andrea 1986. Latratus canis or: The dog's barking. In: Deely, John; Williams, Brooke; Kruse, Felicia (eds.), Frontiers in Semiotics. Bloomington: Indiana University Press, 63-73 (notes pp. 274-276).

[A short version of the text. From the editors' preface (p. xix): “The English text presented in this anthology is a synthesis of these previous papers [Eco et al. 1984, 1985; Eco 1985] made by the editors in consultation with U. Eco, and adding notably the historical layering of the references [pp. 291-322 summed for all chapters of the book]".]

Eco, Umberto 1987. Latratus canis. MicroMega 1: 73-82.

[In Italian. Reprinted as Eco 2012b.]

Eco, Umberto; Lambertini, Roberto; Marmo, Costantino; Tabarroni, Andrea 1989. On animal language in the Medieval classification of signs. (Kelly, Shona, trans.) In: Eco, Umberto; Marmo, Costantino (eds.), On the Medieval Theory of Signs. (Foundations of Semiotics 21.) Amsterdam: John Benjamins Publishing Company, 3-41.

[In English. Reprinting of Eco et al. 1984, with notes on pp. 24-37. References added in this version on pp. 37-41.]

Eco, Umberto 1990. Interpreting animals. In: Eco, Umberto, The Limits of Interpretation. Bloomington: Indiana University Press, 111-122.

[Footnote, p. 111: “This chapter simply summarizes and elaborates upon some aspects of a broader study I made in 1983 in collaboration with three other authors [Eco et al. 1984; 1989]". The book The Limits of Interpretation was reprinted in 1994. For a list of translations of this book (into at least 14 languages) see Eco's bibliography, Beardsworth, Auxier 2017: 691-692.]

Eco, Umberto 2007. Sul latrato del cane (e altre archeologie zoosemiotiche). In: Eco, Umberto, Dall'albero al labirinto: Studi storici sul segno e l'interpretazione. (Studi Bompiani: Campo semiotico.) Milano: Bompiani, 159-202.

[In Italian. The book including this chapter was reprinted by Mondolibri in 2008, and by La nave di Teseo (with new paginations) in 2017. An English translation appeared 
in 2014 (see below). This book has also been published in Greek (2008), Polish (2009), Romanian (2009), French (2010, 2012), Czech (2012), Portuguese (2013), Russian (2016). The chapter was reprinted in Italian as Eco 2012a.]

Eco, Umberto 2010. Se le bestie avessero l'anima. Repubblica, 10 May, 30-31. [A partial Italian version of Eco 2018.]

Eco, Umberto 2012a. Sul latrato del cane (e altre archeologie zoosemiotiche). In: Eco, Umberto, Scritti sul pensiero medievale. Milano: Bompiani, 667-730. [In Italian. Reprinting of Eco 2007.]

Eco, Umberto 2012b. Latratus canis. MicroMega 1/2012. ${ }^{10}$

[In Italian. Republication of Eco 1987 on the occasion of Eco's 80th birthday. Accompanied by Eco's comment from 18 January, 2012: "La ricerca è stata condotta nel corso di un seminario all'Università di Bologna da me, Andrea Tabarroni, Costantino Marmo, Roberto Lambertini (A. A. 1982-83). [...] Il presente articolo riproduce una conferenza tenuta da me a Lovanio e alla Yale University nel 1984. Appare a firma mia perché rappresenta una sintesi degli altri lavori citati, ma per quanto riguarda le idee che vi sono esposte ritengo debba essere considerato opera collettiva che deve essere accreditata anche agli altri tre autori." "11]

Eco, Umberto 2014. The dog that barked (and other zoosemiotic archaeologies). In: Eco, Umberto, From the Tree to the Labyrinth: Historical Studies on the Sign and Interpretation. (Oldcorn, Anthony, trans.) Cambridge: Harvard University Press, 171-222.

[In English. Translation of Eco 2007. Accompanied by Eco's remark (p. 171): “The second part of this essay chapter ${ }^{12}$ incorporates a research project that first appeared under my name, together with those of Roberto Lambertini, Costantino Marmo, and Andrea Tabarroni. The project took shape in a seminar on the history of semiotics at the University of Bologna (during the academic year 1982-1983). [...] For the present book, I have rewritten it, taking into account contributions that have appeared more recently, unburdening it of a number of quotations and erudite notes, and changing the order of the sections. Our original research project identified the classifications

10 See http://temi.repubblica.it/micromega-online/buon-compleanno-umberto-eco/.

11 "Research was conducted by myself, Andrea Tabarroni, Costantino Marmo, and Roberto Lambertini during a seminar at the University of Bologna (academic year 1982-83). [...] The present article reproduces a conference I held at Leuven and Yale University in 1984. It appears with my signature because it represents a synthesis of the other cited works, but as concerns the ideas that are expounded in it I believe that it should be considered a collective work that must be credited to the other three authors as well."

12 The two parts of this essay are: 4.1. Animals from Antiquity to the Middle Ages (pp. 173194), and 4.2. Latratus Canis (pp. 194-222). 
in order of complexity, regardless of whether they had appeared before or after one another, whereas in this version I have followed the chronological order, at least within the two traditions - Stoic-Augustinian and Aristotelian-Boethian - because what most concerned me was to underscore the conflict, continually latent, between the correlational and inferential notions of the sign. Hence, [...] the other three authors are not to be considered responsible for the present draft. It should be understood, however, that, without their collaboration, my own ideas on the latratus canis would have remained as inarticulate as the gemitus infirmorum." The translator adds (p. 172), that this "is a new English translation of Eco's Italian text, itself revised for inclusion in the present volume".]

Eco, Umberto; Lambertini, Roberto; Marmo, Costantino; Tabarroni, Andrea 2016. Latratus canis. In: Eco, Umberto, Dal "Latratus canis" alle Tecniche di citazione nel medioevo. (Lezione Spoletine 2.) Spoleto: Fondacione Centro Italiano di Studi sull' alto Medioevo, 3-52.

[In Italian. An anastatic reprinting of Eco et al. 1985. Pp. 3-47 (1181-1225): "Latratus canis"; pp. 49-52 (1227-1230): "Discussione sulla lezione Eco".]

Eco, Umberto 2018. Animal language before Sebeok. Sign Systems Studies 46(2/3): 365-377.

[The publication in this volume of a talk given in English in 2002. It does mention being related to Eco et al. 1985, yet is a new text, focusing on the animal communication studies of the 17th and 18th centuries. Partially published in Italian as Eco 2010.] ${ }^{13}$

\section{References}

Beardsworth, Sara G.; Auxier, Randall E. (eds.) 2017. The Philosophy of Umberto Eco. (The Library of Living Philosophers 35.) Chicago: Open Court.

Campbell, Gordon Lindsay (ed.) 2014. The Oxford Handbook of Animals in Classical Thought and Life. Oxford: Oxford University Press..

Crane, Susan 2013. Animal Encounters: Contacts and Concepts in Medieval Britain. Philadelphia: University of Pennsylvania Press.

Cuneo, Pia F. (ed.) 2014. Animals and Early Modern Identity. Farnham: Ashgate.

Eco, Umberto 1976. A Theory of Semiotics. Bloomington: Indiana University Press.

- 1988. On semiotics and immunology. In: Sercarz, Eli E.; Celada, Franco; Michison, N. Avrion; Tada, Tomio (eds.), The Semiotics of Cellular Communication in the Immune System: Proceedings of the NATO Advanced Research Workshop on the Semiotics of Cellular Communication in the Immune System held at Il Ciocco, Lucca, Italy, September 9-12, 1986. (Nato ASI Series 23.) Berlin: Springer, 3-15.

13 Acknowledgements. I thank Ene-Reet Soovik and Remo Gramigna for their help. The work belongs to IUT2-44 of the Estonian Ministry of Education and Research. 
- 1999[1997]. Kant and the Platypus: Essays on Language and Cognition. (McEwen, Alastair, trans.) San Diego: A Harvest Book, Harcourt, Inc.

- 2009. On the ontology of fictional characters: A semiotic approach. Sign Systems Studies 37(1/2): 82-98.

- 2017. Intellectual autobiography. In: Beardsworth, Sara G.; Auxier, Randall E. (eds.), The Philosophy of Umberto Eco. (The Library of Living Philosophers 35.) Chicago: Open Court, 3-65.

- 2018a[2002]. Animal language before Sebeok. Sign Systems Studies 46(2/3): 365-377.

- 2018b[1988]. Giorgio Prodi and the lower threshold of semiotics. Sign Systems Studies 46(2/3): 343-351.

Fabry-Tehranchi, Irène; Russakoff, Anna (eds.) 2014. L'Humain et l'Animal dans la France médiévale (XIIe-XVe s.)/Human and Animal in Medieval France (12th-15th c.). Amsterdam: Rodopi.

Favareau, Donald (ed.) 2010. Essential Readings in Biosemiotics: Anthology and Commentary. (Biosemiotics 3.) Berlin: Springer.

Fögen, Thorsten 2014. Animal communication. In: Campbell, Gordon Lindsay (ed.), The Oxford Handbook of Animals in Classical Thought and Life. Oxford: Oxford University Press, 216232.

Kull, Kalevi 2017a. On the limits of semiotics, or the thresholds of/in knowing. In: Thellefsen, Torkild; Sørensen, Bent (eds.), Umberto Eco in His Own Words. (Semiotics, Communication and Cognition 19.) Berlin: De Gruyter Mouton, 41-47.

- 2017b. Umberto Eco and John Deely: What they shared. Sign Systems Studies 45(1/2): 194204.

Kull, Kalevi 2018. Umberto Eco on biosemiotics of Giorgio Prodi. Sign Systems Studies 46(2/3): 352-364.

Langdon, Alison (ed.) 2018. Animal Languages in the Middle Ages: Representations of Interspecies Communication. London: Palgrave MacMillan.

Mackenzie, Louisa; Posthumus, Stephanie (eds.) 2015. French Thinking about Animals. East Lansing: Michigan State University Press.

Maran, Timo; Martinelli, Dario; Turovski, Aleksei (eds.) 2011. Readings in Zoosemiotics. (Semiotics, Communication and Cognition 8.) Berlin: De Gruyter Mouton.

Marmo, Costantino 2018. Eco's "latratus canis": A memory of the backstage. Sign Systems Studies 46(2/3): 378-382.

Nöth, Winfried 2000. Umberto Eco's semiotic threshold. Sign Systems Studies 28: 49-61.

Percival, Keith W. 1982. An eighteenth-century view of animal communication. Semiotica 39(1/2): 55-73.

Resnick, Irven M.; Kitchell, Kenneth F. Jr. 1996. Albert the Great on the 'language' of animals. American Catholic Philosophical Quarterly 52(1): 41-61.

Rodríguez Higuera, Claudio J.; Kull, Kalevi 2017. The biosemiotic glossary project: The semiotic threshold. Biosemiotics 10(1): 109-126.

Sayers, William 2009. Animal vocalization and human polyglossia in Walter of Bibbesworth's thirteenth-century domestic treatise in Anglo-Norman French and Middle English. Sign Systems Studies 37(3/4): 525-541.

Serjeantson, Richard W. 2001. The passions and animal language, 1540-1700. Journal of the History of Ideas 62(3): 425-444. 
Tabarroni, Andrea 1988. On articulation and animal language in ancient linguistic theory. Versus 50/51: 103-121.

Yin, Sophia 2002. A new perspective on barking in dogs (Canis familaris). Journal of Comparative Psychology 116(2): 189-193.

\section{Разыскания Умберто Эко и его коллег в истории ранней зоосемиотики: комментарий и библиография}

В статье представлен комментарий к тексту Умберто Эко «Язык животных до Себеока» (2002) и аннотированная библиография различных версий статьи о 'latratus canis', которую Эко опубликовал вместе с Роберто Ламбертини, Костантино Мармо и Андреа Табаррони впервые в 1984 году.

\section{Umberto Eco ja tema kolleegide uurimus zoosemiootika varasest ajaloost: kommentaar ja bibliograafia}

Artiklis kommenteeritakse Umberto Eco teksti “Loomade keel Sebeoki eel” (2002) ning esitatakse annoteeritud bibliograafia loomade keele käsitluste ajaloole pühendatud artiklitest, mille autoriteks on Umberto Eco ning tema kolleegid Roberto Lambertini, Costantino Marmo ja Andrea Tabarroni ning mille esimene variant avaldati aastal 1984. 